\title{
本邦における Pagetoid spread を伴う肚門管癌の治療成績
}

\author{
佐伯 泰壃山田一隆岩本一亜田中正文 \\ 福永 光子 野口 忠昭 伊禮 靖苗 \\ 大腸肛門病センター高野病院消化器外科
}

Pagetoid spread を伴う肚門管癌は比較的稀な疾患なためまとまった報告例はなく治療成績もほとんど 報告されていない.今回臨床病理学的特徵と治療成績を明らかにするために本邦で治療された 81 例の検 討を行った。平均年齢 70.2 歳, 男女比 1 対 1.3. 自覚症状を $97 \%$ に認め, 治療前に原発巣同定困難な症例 が 32\%認め, 粘膜内癌を含む早期例でも Pagetoid spread を認めていた. 原発性 Paget 病と Pagetoid spread の皮疹の鑑別に免疫染色が行われ GCDFP - /CK20+/CK7+ が多かった. 切除範囲同定のための術前 mapping 生検が $46 \%$ 行われ，治療の多くは直腸切断術が行われていた。 5 年生存率は $45.4 \%$ で 5 年累積再発 率は $51.3 \% て ゙$ 爯径リンパ節と局所に多く認め，通常の肛門管癌よりやや予後不良であった。

索引用語 : 肚門管癌, パジェトイド現象, CK20, CK7, 累積再発率

\section{はじめに}

乳房外 Paget 病は年間 10 万人あたり 0.7 人発症 ${ }^{1)}$ する比較的稀な悪性腫瘍で (1) 表皮内から始まる病 巣が水平方向に表皮内，付属器上皮内を拡大し，そ の後, 真皮内に浸潤性にしていく原発性乳房外 Paget 病と (2) 肛門癌に代表される粘膜の癌腫が上皮内を 進展し，開口部皮膚にも及んできて臨床的に皮膚病 巣が認められる続発性乳房外 Paget 病に分類され, 皮膚に進展している状態を Pagetoid spread あるい は Paget 現象と呼んでいる2。.

原発性乳房外 Paget 病と続発性乳房外 Paget 病で は治療方針が異なるため皮疹の鑑別が必要となるが Hematoxylin-Eosin（H\&E）染色での鑑別は困難な ことが多く免疫染色での鑑別が有用とされている. その際アポクリン汗腺・エクリン汗腺に存在する GCDFP15, 消化管上皮や膀胱上皮のマーカーである サイトケラチン 20 (CK20), および消化管以外の腺 上皮（肛門腺など）や内皮細胞のマーカーであるサ イトケラチン 7 (CK7) の組み合わせなどで判断さ れる ${ }^{3,4)}$.

乳房外 Paget 病の発生部位として外院部が最多 $(65-70 \%)$ であり，次に肛門周囲 $(5.2-20 \%)^{5.6)}$ に 多いとされている。肛門周囲 Paget 病は Darier and
Couilland ${ }^{7)}$ により 1893 年に最初の報告がされた. 続 発性肛門周囲 Paget 病に分類される Pagetoid spread を伴う肛門管癌は比較的稀とされ少数例での症例報 告はされているがまとまった報告例はない。そのた め治療成績の報告はほとんどされていない。今回臨 床病理学的特徵と治療成績を明らかにするために今 まで報告された症例と自験例を含めた 81 例の検討 を行った。

\section{対象・方法}

肛門管癌 - 直腸癌 - Paget 病 - Pagetoid 現象 · Pagetoid spread をキーワードとして 2000 年から 2019 年までの間に医学中央雑誌に収められた論文 （会議録を除く）のうち原発性肛門周囲 Paget 病を 除く Pagetoid spread を伴う直腸肛門管癌 76 例と 2001 年から 2018 年までの当院で経験した Pagetoid spread を伴う直腸肛門管癌 5 例を含めた 81 例を検 討の対象とした，臨床病理学的特徵・治療方法・治 療成績について検討した。生存率・累積再発率は Kaplan-Meier 法を用いた。

\section{結 果}

（1）臨床所見：平均年齢は 70.2 歳で女性が $57 \%$ と多かった. 診断時症状を認めた症例が 76 例 (94\%) 
あり直腸肛門管癌によると考えられる症状が 40 例, 肛門周囲皮膚によると考えられる症状が 38 例であっ た。原発巣は肛門管（P）が 74 例で，下部直腸肛門 管 $(\mathrm{RbP})$ が 7 例で全例肚門管に認めていた。原発 巣の同定が治療前に困難であった症例が 26 例 (32\%) 認めた. Pagetoid spread 径は平均 $73.2 \mathrm{~mm}$ で治療 前に Pagetoid spread と診断されていたのは 57 例 （70\%）のみであった，組織型は，高・中分化腺癌, 粘液癌が約 $2 / 3$ を占めていた．原発巣の深達度は, $\mathrm{M} \cdot \mathrm{SM}$ と比較的早期の症例が 34 例 $(42 \%)$ 認め, リンパ節転移は 24 例 $(30 \%)$ に認めた。リンパ節転 移のうち爯径リンパ節転移は 13 例 $(16 \%)$ に認めて いた（Table 1-3）.

病理検査にて免疫染色は 65 例 $(80 \%)$ に施行され $\mathrm{CK} 20+$ は 61 例中 59 例 $(97 \%), \mathrm{CK} 7+$ は 44 例中 27 例 $(61 \%)$, GCDFP15 - は 48 例中 47 例 $(98 \%)$ で 1 例のみ GCDFP15 弱陽性 (+/-) であった（Table 4, Fig. 1). CK20 と CK7 の組み合わせ 44 例では CK20+ $/ \mathrm{CK} 7+26$ 例 (59\%), CK20+/CK7 - 17 例 $(39 \%)$, $\mathrm{CK} 20-/ \mathrm{CK} 7+1$ 例 $(2 \%), \mathrm{CK} 20-/ \mathrm{CK} 7-0$ 例 （０％）であった。また CK の免疫染色がされた粘液 癌 8 例は全例 CK20+/CK7+であった（Table 5).

(2) 治療方法: 初回治療は 77 例に手術が施行され 直腸切断術や局所切除が多く施行されていた。しか し直腸切断術を施行された 58 例中 2 例は断端陽性 で追加の局所切除が施行され, また局所切除 17 例中 14 例は断端陽性で追加治療が施行されていた. 初回 非手術 4 例中 3 例は化学放射線治療が施行され 2 例 は計画的な直腸切断術が施行されていた (Table 6). 手術例のうち Pagetoid spread の範囲を同定するた めの mapping 生検は 36 例（46\%）に施行されてい た (Table 2, Fig. 2).

(3) 治療成績: 平均観察期間は 21.2 力。再発は 遺残・不明を除く 70 例中 19 例に認め部位としては 鼡径リンパ節と局所に多く再発を認め, 5 年累積再 発率は $51.3 \%$ であった (Fig. 3). 5 年生存率は $45.4 \%$ で Stage 別では Stage 0：I：II：III：IVはそれぞれ 100\%：67.9\%：0\%：42.5\%（3 年)：0％であった (Fig. 4).

\section{考察}

乳房外 Paget 病のうち肛門周囲 Paget 病において は, 直腸肛門管癌を $33-80 \%{ }^{6.8 .9)}$ と高頻度認めてお
り原発性より続発性の肛門周囲 Paget 病が多く消化 管精査が重要となる。また歯状線にかかる直腸肛門 管癌の場合 Pagetoid spread が肛門周囲にないか念 頭において治療にあたる必要があると考えられる。 肛門管癌 122 例中 Pagetoid spread を伴うのは 18 例 $(6.1 \%)^{10)}$ 報告されているが, 当院で 2001 年から 2018 年に治療した肚門管腺癌 78 例中 Pagetoid spread を 認めたのは 5 例（6.4\%）であり今までの報告とほぼ 同じであった。

原発性肛門周囲 Paget 病と続発性肛門周囲 Paget 病の皮疹は病理組織学的にどちらも表皮内に円形で 大型の Paget 細胞を認める. 原発性では管腔構造形 成は少なく，アポクリン腺様で，一様な小型な腺組 織で，腫瘍細胞は均一，ムチンの貯留は認めず，裂 隙形成も認めないとされている。一方続発性では管 腔構造形成を多く認め, 原発臓器様で, 多様な大型 な腺組織で, 腫瘍細胞は多形, ムチン貯留を認め, 裂隙形成も認めるとされている ${ }^{11,12)}$. 電顕所見で, 原 発性の Paget 細胞は互いに小型のデスモゾームで結 合し，上皮組織由来を示唆する隣接のケラチノサイ トとも結合するが, 続発性の Pagetoid spread 細胞 は未熟なデスモゾームと微繊毛を有し，胞体内に腺 癌を示唆する微小腺腔形成所見がみられ肚門管腺癌 と類似すると報告されている ${ }^{13)}$. しかし通常の $\mathrm{H} \& \mathrm{E}$ 染色にて原発性の Paget 細胞と続発性の Pagetoid spread 細胞の鑑別は非常に困難である.

Paget 細胞と Pagetoid spread 細胞の鑑別には免 疫染色が有用と報告されている。アポクリン汗腺・ エクリン汗腺に存在する GCDFP15，および消化管 上皮や膀胱上皮のマーカーである CK20 用いて鑑 別を行う. Paget 細胞では, GCDFP15+/CK20-とな り, Pagetoid spread 細胞では, GCDFP15-/CK20+ となることが多く鑑別に役立つとされている ${ }^{3}$. しか し直腸肛門管腺癌の Pagetoid spread 細胞では CK $20+/ \mathrm{CK} 7$-が $87-95 \%$ と報告されており ${ }^{4)}$, 全例 CK

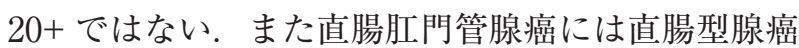
と肚門腺由来癌があり, 直腸型腺癌では $65-95 \%{ }^{14-16)}$ は CK20+/CK7 - であるが CK7+が $13-22 \%{ }^{14,16-18)}$ 存在する。肚門腺および肛門腺由来癌は CK20 - / $\mathrm{CK} 7+{ }^{17.19)}$, 粘液癌は $\mathrm{CK} 20+/ \mathrm{CK} 7+{ }^{20.21)}$ と報告されて いる．以上をまとめると原発性肛門周囲 Paget 病で は GCDFP15+/CK7+/CK20 -であるが, 直腸肛門管 腺癌による続発性肚門周囲 Paget 病では GCDFP15 
Table 1 Characteristics of 81 Patients

\begin{tabular}{|c|c|}
\hline Factor & No. $(\%)$ \\
\hline Age (years) & $70.2 \pm 9.7 \quad(49-92)$ \\
\hline $\begin{array}{l}\text { SEX } \\
\text { male } \\
\text { female }\end{array}$ & $\begin{array}{ll}35 & (43) \\
46 & (57)\end{array}$ \\
\hline $\begin{array}{l}\text { Presenting Symptom } \\
\text { yes } \\
\text { no }\end{array}$ & $\begin{array}{cc}76 & (94) \\
5 & (6)\end{array}$ \\
\hline $\begin{array}{l}\text { Location } \\
\mathrm{P} \\
\mathrm{RbP}\end{array}$ & $\begin{array}{cc}74 & (91) \\
7 & (9)\end{array}$ \\
\hline $\begin{array}{l}\text { Identification of primary lesion } \\
\text { possible } \\
\text { difficult }\end{array}$ & $\begin{array}{ll}55 & (68) \\
26 & (32)\end{array}$ \\
\hline $\begin{array}{l}\text { Primary origin } \\
\text { rectal } \\
\text { anal gland } \\
\text { unknown }\end{array}$ & $\begin{array}{ll}18 & (22) \\
31 & (38) \\
32 & (40)\end{array}$ \\
\hline $\begin{array}{l}\text { Histology } \\
\text { tubl/2 } \\
\text { adeno ca (unknown grade) } \\
\text { por/sig } \\
\text { muc } \\
\text { NEC/MANEC }\end{array}$ & $\begin{array}{cc}38 & (47) \\
11 & (14) \\
13 & (16) \\
16 & (20) \\
3 & (4)\end{array}$ \\
\hline Size of tumor $(\mathrm{mm})$ & $24.9 \pm 16.5(3-70)$ \\
\hline $\begin{array}{l}\text { Type } \\
\text { Type0 } \\
\text { Type1-4 } \\
\text { Type5 } \\
\text { unknown } \\
\text { difficult to identify }\end{array}$ & $\begin{array}{cc}30 & (37) \\
25 & (31) \\
12 & (15) \\
7 & (9) \\
7 & (9)\end{array}$ \\
\hline $\begin{array}{l}\text { Depth } \\
\text { M } \\
\text { SM } \\
\text { MP } \\
\text { A } \\
\text { AI } \\
\text { unknown }\end{array}$ & $\begin{array}{cc}14 & (17) \\
20 & (25) \\
16 & (20) \\
17 & (21) \\
6 & (7) \\
8 & (10)\end{array}$ \\
\hline $\begin{array}{l}\text { LN metastasis } \\
\text { yes } \\
\text { no } \\
\text { unknown }\end{array}$ & $\begin{array}{cc}24 & (30) \\
53 & (65) \\
4 & (5)\end{array}$ \\
\hline $\begin{array}{l}\text { Inguinal LN metastasis } \\
\text { yes } \\
\text { no } \\
\text { unknown }\end{array}$ & $\begin{array}{ll}13 & (16) \\
66 & (81) \\
2 & (2)\end{array}$ \\
\hline $\begin{array}{l}\text { Distant metastasis } \\
\text { yes } \\
\text { no } \\
\text { unknown }\end{array}$ & $\begin{array}{cc}5 & (6) \\
73 & (90) \\
3 & (4)\end{array}$ \\
\hline $\begin{array}{l}\text { Stage* } \\
\text { Stage 0 } \\
\text { Stage I } \\
\text { Stage II } \\
\text { Stage III } \\
\text { Stage IV } \\
\text { unknown }\end{array}$ & $\begin{array}{cc}14 & (17) \\
30 & (37) \\
8 & (10) \\
20 & (25) \\
5 & (6) \\
4 & (5)\end{array}$ \\
\hline
\end{tabular}

*Japanese Classification of Colorectal, Appendiceal, and Anal Carcinoma ( $9^{\text {th }}$ Edition) 
Table 2 Characteristics of Pagetoid Spread in 81 Patients

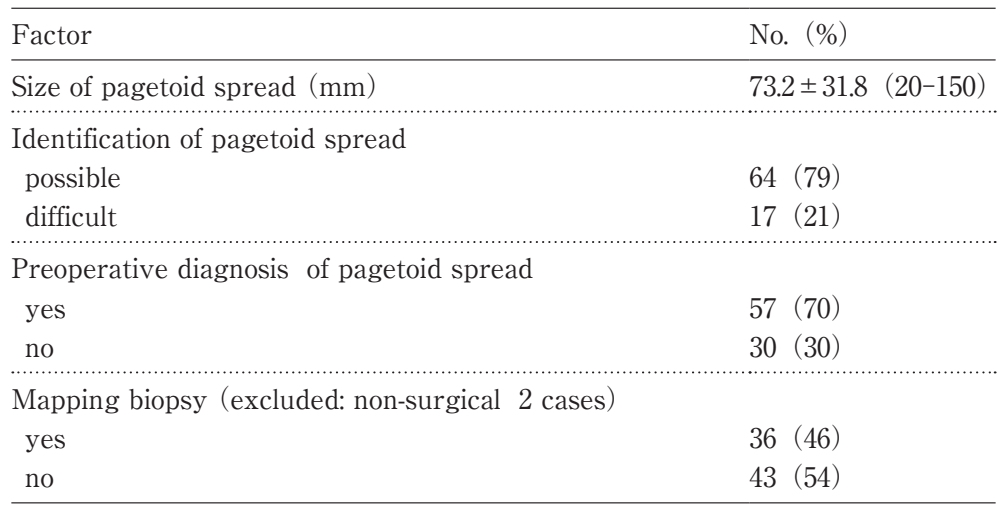

Table 3 Presenting Symptoms in 81 Patients

\begin{tabular}{|c|c|c|}
\hline Symptom & & No. $(\%)$ \\
\hline Yes & & $76(94)$ \\
\hline \multirow[t]{6}{*}{ Symptoms of primary tumor } & & $40(49)$ \\
\hline & anal bleeding & $20(25)$ \\
\hline & anal pain & $14(17)$ \\
\hline & anal tumor & $10(12)$ \\
\hline & defecation & $2(3)$ \\
\hline & incontinence & $1(1)$ \\
\hline \multirow[t]{4}{*}{ Symptoms of pagetoid spread } & perianal pain & $\begin{array}{r}38 \\
5(47)\end{array}$ \\
\hline & dermatitis & $27(33)$ \\
\hline & perianal itching & $16(20)$ \\
\hline & perianal tumor & $3(4)$ \\
\hline \multirow[t]{3}{*}{ Symptoms of others } & & $7(9)$ \\
\hline & inguinal tumor & $3(4)$ \\
\hline & others & $4(5)$ \\
\hline
\end{tabular}

Patients may have had more than one symptom.

Table 4 Immunohistochemistry for Patients

\begin{tabular}{lc}
\hline IHC & No. $(\%)$ \\
\hline yes $:$ no & $65: 16(80: 20)$ \\
CK20 (+) $:(-)$ & $59: 2(97: 3)$ \\
CK7 $(+):(-)$ & $27: 17(61: 39)$ \\
GCDFP15 $(+):(+/-):(-)$ & $0: 1: 47(0: 2: 98)$ \\
\hline
\end{tabular}

- /CK20+ or -/CK7+ or - となるため注意を要す る. 今回の検討において CK20 と CK7 の組み合わせ では, CK20+/CK7+が59\%, CK20+/CK7 -が 39\%,

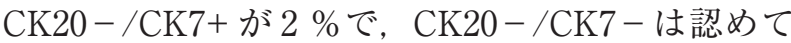
いなかった. CK20+/CK7－は以前の報告4) より少な く, CK20+/CK7+ が約 6 割と最も多く認めた。また 粘液癌において全例 CK20+/CK7+を示しており以 前の報告と一致していた.
Pagetoid spread の発生機序については, 直腸肛 門管癌の直接浸潤であるという報告が多いが，森谷 $ら^{22)}$ は, Pagetoid spread を伴う肛門腺由来の上皮内 癌症例を報告し肛門周囲 Pagetoid spread の初期像 であることを報告している.すべての肛門周囲 Pagetoid spread 症例は, 肛門腺より腫瘍細胞が発生し, 接着性の強い印環細胞などが肛門腺の基底膜を破ら ずに, 肚門小窩, 肛門上皮内へと連続的に進展, 浸潤 

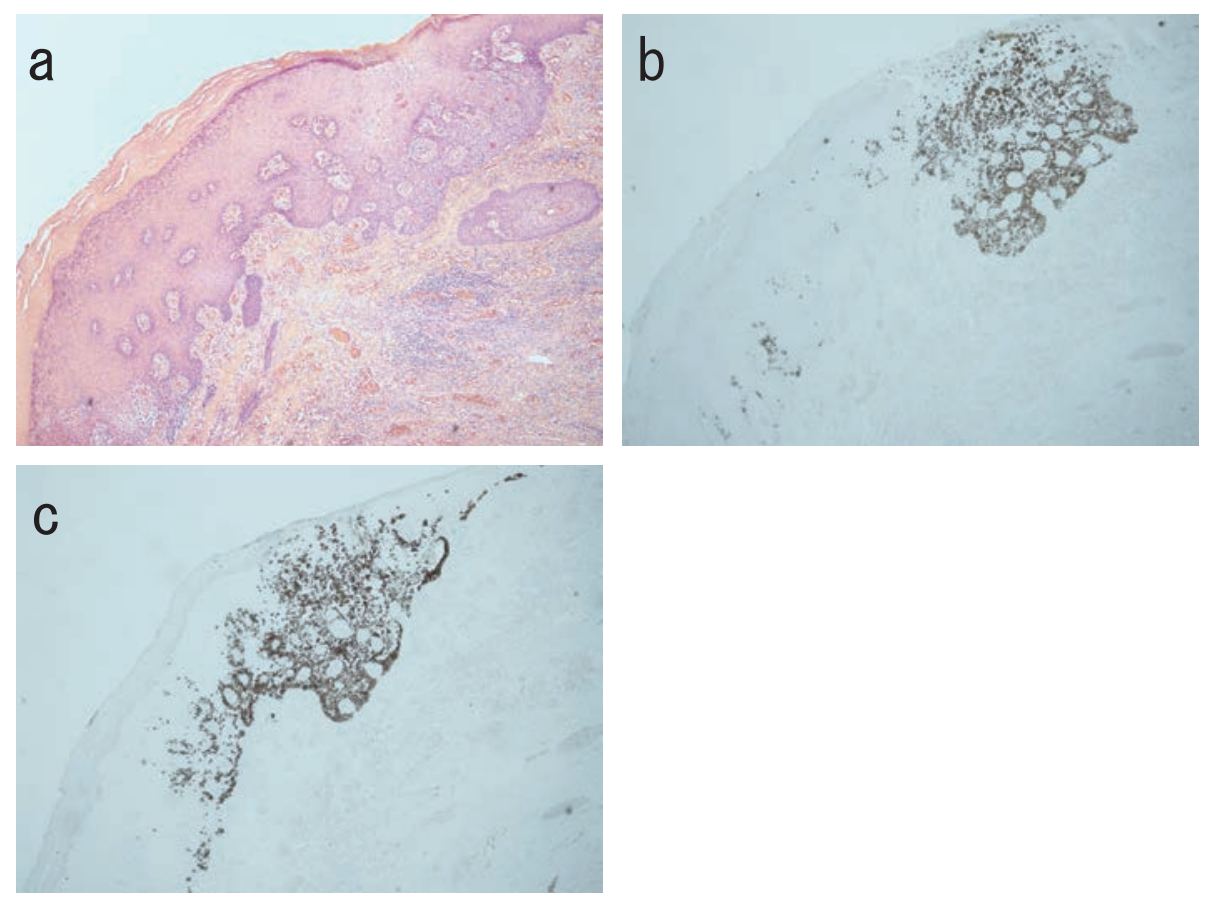

Fig. 1 The Immunohistochemical Stains of the Perianal Area a : Hematoxylin-Eosin $(\times 40)$

b : Positive for CK20 $(\times 40)$

c : Positive for CK7 $(\times 40)$

Table 5 Results for CK20 \& CK7

\begin{tabular}{|c|c|c|c|c|c|c|c|c|}
\hline & \multirow[b]{2}{*}{ No. $(\%)$} & \multicolumn{3}{|c|}{ Origin } & \multicolumn{4}{|c|}{ Histology } \\
\hline & & rectal type & anal gland & unknown & tubl/2 & por/sig & muc & others \\
\hline CK20 (+)/CK7 (+) & $26(59)$ & 8 & 9 & 9 & 11 & 1 & 8 & 6 \\
\hline CK20 (+)/CK7 (-) & $17(39)$ & 4 & 5 & 8 & 9 & 5 & 0 & 3 \\
\hline CK20 (-)/CK7 (+) & $1(2)$ & 0 & 0 & 1 & 0 & 0 & 0 & 1 \\
\hline CK20 (-)/CK7 (-) & $0(0)$ & 0 & 0 & 0 & 0 & 0 & 0 & 0 \\
\hline total & $44(100)$ & 12 & 14 & 18 & 20 & 6 & 8 & 10 \\
\hline
\end{tabular}

してゆくことが始まりではないかと提唱している. しかし Pagetoid spreadを伴う直腸肛門管癌は全例 が肚門腺由来癌ではなく直腸型肚門腺癌も存在する が，いずれにおいても肛門上皮へと進展している. 癌が直接浸潤していく場合は，肚門上皮内のみなら ず皮下組織にも浸潤と思われるが Pagetoid spread は上皮内のみの進展であり特殊な進展形式である. また人工肛門部に発生した結腸癌が人工肛門周囲皮 膚に Pagetoid spread している症例の報告 ${ }^{23)} も あ り$ Pagetoid spreadの発生に関して近接した癌により 扁平上皮内の多分化能を有する細胞が腸上皮化様の 変化を起こすのではないかと考えられる.

Pagetoid spreadの大きさは平均 $53 \mathrm{~mm}^{24)}$ と報告
されているが, 今回の検討では $73.2 \mathrm{~mm}$ と以前の報 告よりかなり大きかった. Pagetoid spread と正常皮 虐との境界が明瞭な症例と, 肉眼的に境界が不明瞭 な症例があり治療前には十分な mapping 生検が必要 と考えられる. Pagetoid spreadの切除マージンは, 乳房外 Paget 病の mapping 生検に準拠し 境界が明 瞭な場合は $1 \mathrm{~cm}$, 不明瞭な場合は $3 \mathrm{~cm}$ 程度マージ ンを確保する必要がある2). 2000-2013 年での Pagetoid spread を伴う肛門管癌 42 例での報告では mapping 生検は 12 例（28.8\%）とされていたが25), 今回の検討症例では $46 \%$ に施行されており最近では mapping 生検率が上昇していた。 また原発性肚門周 囲 Paget 病の皮疹は, 限局しているのに対して, 続 
Table 6 Therapy for Anal Canal Carcinoma with Pagetoid Spread

\begin{tabular}{|c|c|c|c|c|}
\hline $1^{\text {st }}$ therapy & No. $(\%)$ & & $2^{\text {nd }}$ therapy & No. $(\%)$ \\
\hline \multirow{3}{*}{$\mathrm{LE}^{*}$} & \multirow{3}{*}{$17(21)$} & margin positive & APR & $11(14)$ \\
\hline & & $C$ & LE & $1(1)$ \\
\hline & & & - Radiotherapy & $1(1)$ \\
\hline Sleeve resection & $1(1)$ & \multirow{3}{*}{ margin positive } & \multirow{3}{*}{$\rightarrow \mathrm{LE}$} & \multirow{3}{*}{$2(2)$} \\
\hline APR & $58(72)$ & & & \\
\hline TPE & $1(1)$ & & & \\
\hline Chemotherapy & $1(1)$ & \multirow{2}{*}{ planned } & \multirow[b]{2}{*}{$\rightarrow \mathrm{APR}$} & \\
\hline CRT & $3(4)$ & & & $2(2)$ \\
\hline total & $81 \quad(100)$ & & & $16(20)$ \\
\hline
\end{tabular}

*The depth of LE 17 cases : M $\cdot \mathrm{SM} 10$ cases, MP · A 3cases, Unknown 4cases.

LE: local excision; APR: abdominoperineal resection;

CRT: chemoradiotherapy; TPE: total pelvic exenteration
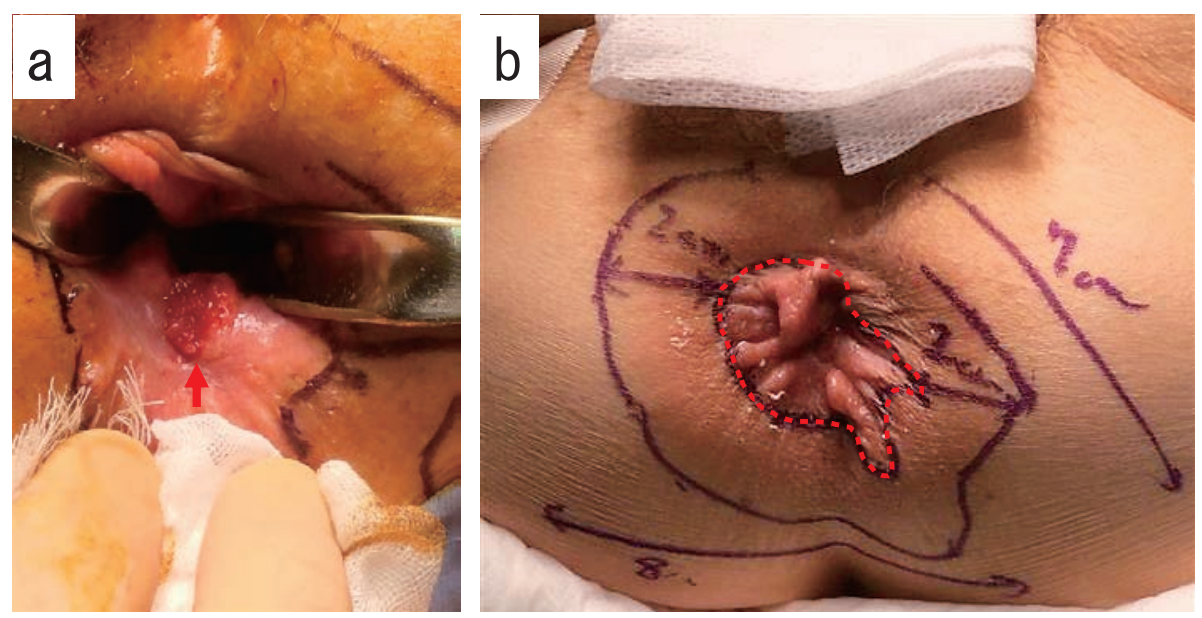

Fig. 2 Macroscopic Findings of the Anal Canal Tumor with Pagetoid spread and Mapping Biopsy

a : The anal canal cancer $(\uparrow)$.

b : The area (O) of pagetoid spread.

発性肛門周囲 Paget 病の皮疹（Pagetoid spread）の 場合は全周性に広がりを認めることが多いと報告さ れている ${ }^{26)}$ そその理由として原発性の場合は肛門周 囲皮膚のある一点から腫瘍が発生するため, 肛門の 辺縁に限局して皮疹を形成するのに対して, Pagetoid spread では消化管悪性腫瘍から遠心性に腫瘍細 胞が表皮内を進展した結果，肚門全周性の皮疹とな り，異なる臨床所見を呈するのではないかと推察さ れている。

原発巣の同定に関して今回の検討では, 術前内視 鏡や CT ・ MRI の画像診断で術前原発巣の同定困難 な症例が 26 例 $(32 \%)$ 認められ，それらの多くは肛 門腺由来癌であった。直腸型腺癌では，直腸肛門内
に隆起性病変として比較的同定しやすいが，肛門腺 由来癌の場合，粘膜下腫瘍様の形態を呈することが 多く比較的早期の場合では同定が困難なことがあり 注意を要する。

治療に関して原発性肚門周囲 Paget 病は，表皮内 浸潤であるため局所切除が基本となることが多いが， 続発性肛門周囲 Paget 病は, 原発巣の根治術が必要 となり病期により異なるが多くの場合直腸切断術が 必要となる. 今回の検討では, 手術例 79 例中 72 例 （91％）に直腸切断術が施行されていたが，深達度 $\mathrm{M} \cdot \mathrm{SM}$ 症例の一部の症例（34 例中 3 例）において 局所切除が施行されていた. Shutze and Gleysteen ${ }^{27}$ は原発性・続発性を含めた肛門周囲 Paget 病の Stage 


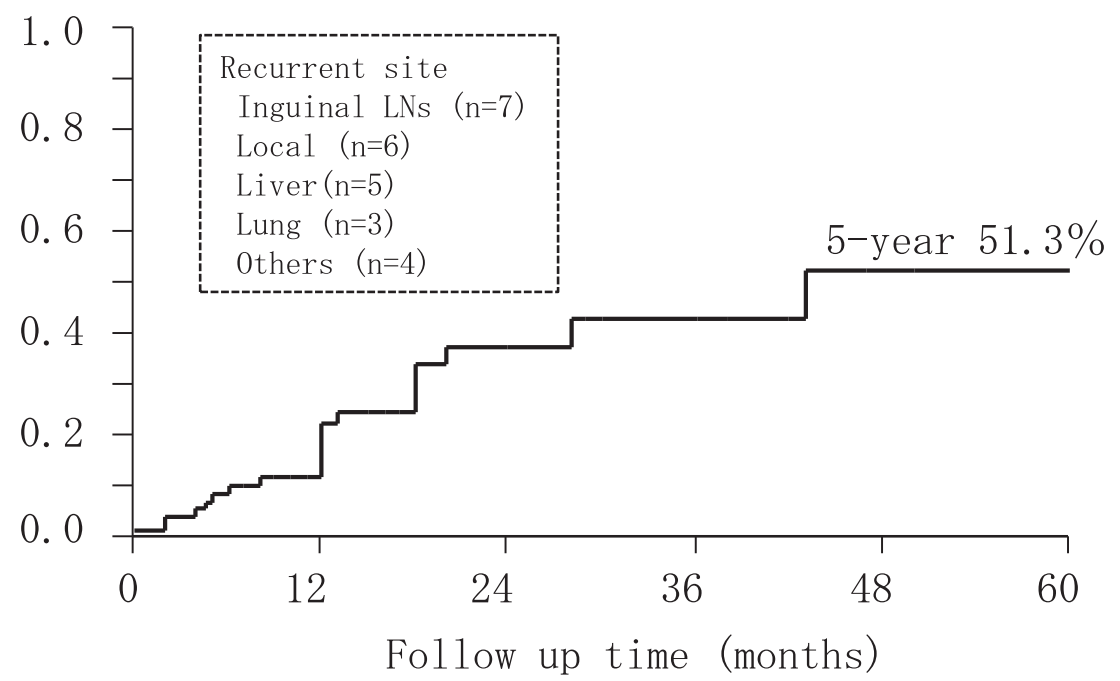

Fig. 3 Cumulative Recurrence Rate for 70 Patients
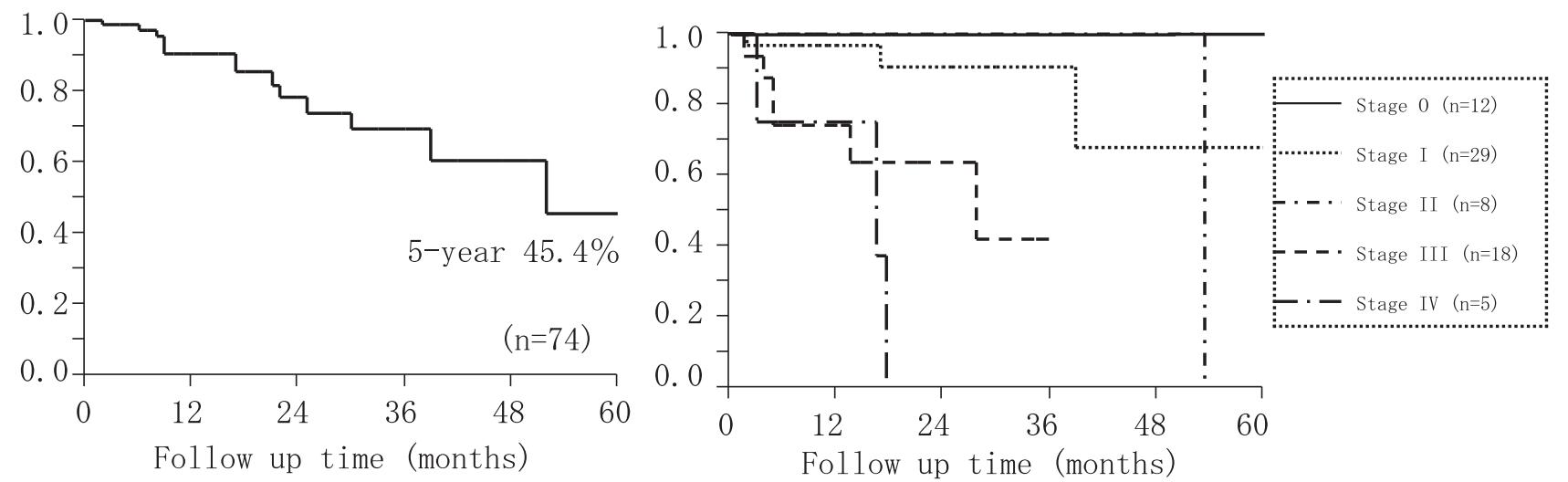

Fig. 4 Overall Survival for 74 Patients

Table 7 Stage \& Management of Perianal Paget's Disease

\begin{tabular}{lll}
\hline Stage & Description & Management \\
\hline I & Paget's cells found in perianal epidermis and adnexae without primary carcinoma & WLE \\
II A & Cutaneous Paget's disease with associated adnexal carcinoma & WLE \\
II B & Cutaneous Paget's disease with associated anorectal carcinoma & APR \\
III & Paget's disease in which associated carcinoma has spread to regional nodes & ILND + WLE/APR \\
IV & Paget's disease with distant metastases of associated carcinoma & CT + RT + LPM \\
\hline
\end{tabular}

WLE: Wide local excision; APR: abdominoperineal resection; ILND: inguinal lymph node dissection;

CT: chemotherapy; RT: radiotherapy; LPM: local palliative management.

分類と推奨する治療法を提唱している (Table 7)。そ の分類においては，直腸肛門管癌による続発性肛門 周囲 Paget 病でリンパ節転移を伴わないものは Stage II B, リンパ節転移を伴うものは Stage III, 遠隔転移 を伴うものはStage IVとしている．推奨する治療法 は Stage II B では直腸切断術, Stage III では爯径リン パ節郭清を伴った直腸切断術, Stage IVでは $5 \mathrm{FU} ・$
$\mathrm{MMC}$ などの化学療法・放射線治療・姑息的局所療 法となっている.

肛門管腺癌の絾径リンパ節転移は $19.9-25 \%{ }^{28-30)}$, 肛門管腺癌のうち管内型 (直腸型) ・ 管外型 (肛門腺由 来・痔瘻癌など）の単径リンパ節転移は各々 $19.6 \%$, $29.9 \%{ }^{29)}$ と報告されている. 今回の Pagetoid spread を伴う肛門管癌における鼡径リンパ節転移は粘膜内 
癌と記載なしを除く 65 例中 13 例 $(20 \%)$ に認め通常 の肛門管癌と同程度の営径リンパ節転移頻度であっ た。爯径リンパ節の郭清に関しては, リンパ漏 $(22$ $-80 \%)$, 創哆開 $(17-65 \%)$, 創感染 $(6-24 \%)$, リンパ浮腫 $(22-40 \%)$ といった術後合併症 ${ }^{31)}$ が高頻 度で発生するため, 現在では予防的な爯径リンパ節 郭清は積極的には行われていないのが現状である ${ }^{30}$. また予防的奧径リンパ節郭清が生存に寄与するエビ デンスはないとされている ${ }^{32}$.

肛門管腺癌の 5 年生存率は $52-60 \%{ }^{28.33)}$ と報告さ れている。一方 Pagetoid spread を伴う直腸肛門管 癌の 5 年生存率は $26 \%{ }^{34)}$ と予後不良という報告と $57.7 \%{ }^{35)}$ と通常の肛門管癌と変わらないという報告 もあるがいずれも 23 例， 32 例と小数例での報告で あり, 現在のところ予後不明である. 今回の 81 例で の検討では 5 年生存率は $45.4 \%$ であり通常の肛門管 癌と比較し同等からやや不良と思われた。再発は遺 残・不明を除く 70 例中 19 例 $(27 \%)$ に認め部位と しては営径リンパ節と局所に多く再発を認めた． 5 年累積再発率は $51.3 \%$ であた。乳房外 Paget 病術 後再発率は $44-60 \%{ }^{36)}$ と報告されているがこれらは 原発性と続発性を含めての報告であり，続発性であ る Pagetoid spread を伴う肚門管癌での報告はない.

局所進行直腸癌に対して欧米では術前化学放射線 療法が積極的に行われており，本邦においても近年 局所制御目的の術前化学療法や化学放射線療法を行 う施設が増えてきているが, Pagetoid spread を伴う 肛門管腺癌に対する一定の見解は今のところない. しかし術前化学放射線療法や放射線療法で $\mathrm{pCR}$ が得 られた Pagetoid spread を伴う肛門管腺癌の報告 ${ }^{37)}$ や術前放射線療法後手術を行った症例 ${ }^{38)}$ も散見され るようになっており今後化学放射線治療は治療オプ ションとなる可能性はあると考えられる。近年では 手術手技の向上により下部直腸肛門管腺癌に対して 超低位前方切除術や括約筋間直腸切除術といった肚 門温存手術が行われるようになってきている ${ }^{39)}$. し かし特に歯状腺に癌が及ぶ場合には肉眼的に同定困 難な Pagetoid spread が存在する40-42) ことを念頭に 置いて治療方針を決定する必要があると考えられた。

\section{結語}

肛門周囲の改善しない皮疹を認める場合や肚門管 癌を認める場合には Pagetoid spread を念頭に置く
必要があり, 十分な画像診断・触診・生検にて正確 な診断を行い，その病態に基づいた適切な治療を行 う必要があると考えられた。

利益相反：なし

\section{文献}

1) van der Linden M, Meeuwis KAP, Bulten J, et al: Paget Disease of the Vulva. Crit Rev Oncol Hematol 101 : 60-74, 2016

2) 日本皮膚悪性腫瘍学会編：皮膚悪性腫瘍取扱い規約 第 2 版. 金原出版, 東京, 2015, p63

3）阿尾理一, 梶原由規, 神藤英二ほか: 乳房外 Paget 病. 臨外 74:738-742, 2019

4) 中原千尋, 藤原謙次, 山崎 徹ほか: ポリープ切除後, 急速に Paget 様進展した肛門管腺癌の 1 例. 日臨外会誌 $70: 2104-2108,2009$

5）稲次直樹, 吉川周作, 増田 勉ほか：稀な肛門癌の診断 と治療 基底細胞癌および類基底細胞癌, Paget 病, Bowen 病. 臨外 63:245-255, 2008

6) Chanda JJ: Extramammary Paget's disease: prognosis and relationship to internal malignancy. J Am Acad Dermatol 13 : 1009-1014, 1985

7) Darier J, Coulillad P: Sur un cas de maladie de Paget de la resion perinea-anale et scrotal. Ann de Dermatol de Syph 4 : 25-31, 1893

8) Leonard D, Beddy D, Dozois EJ: Neoplasms of anal canal and perianal skin. Clin Colon Rectal Surg 24 : 5463, 2011

9) Shi C, Argani P: Synchronous Primary Perianal Paget's Disease and Rectal Adenocarcinoma: Report of a Hitherto Undescribed Phenomenon. Int J Surg Pathol 17 : 42-45, 2009

10）松田圭二, 樋渡信夫, 安達実樹ほか：日本における肚門 部腫瘍の集計。胃と腸 38：1303-1309, 2003

11）斎藤 京, 稲積豊子, 清水 宏ほか: 肚囲に Paget 現象 を呈した肚門管癌の 1 例。臨皮 $52: 176-178,1998$

12) Ackerman AB: Differential Diagnosis in Dermatopathology. Vol.3. Lea and Febiger, Pennsylvania, 1992, p130133

13）小杉光世, 王 敏, 寺畑信太郎ほか：肛囲, 外陰 - 腟 に Pagetoid spread を伴った肚門管腺癌の 1 例. 日本大 腸肛門病会誌 $55: 359-365,2002$

14) Saad RS, Silverman JF, Khalifa MA, et al: CDX2, cytokeratins 7 and 20 immunoreactivity in rectal adenocarcinoma. Appl Immunohistochem Mol Morphol 17 : 196201, 2009

15) Wang NP, Zee S, Zarbo RJ, et al: Coordinate expression of cytokeratins 7 and 20 defines unique subsets of carcinoma. Appl Immunohistochem Mol Morphol 3 : 99-107, 1995

16) Chu P, Wu E, Weiss LM: Cytokeratin 7 and cytokeratin 20 expression in epithelial neoplasms: a survey of 435 cases. Mod Pathol 13:962-972, 2000 
17) Bayrak R, Haltas H, Yenidunya S: The value of CDX2 and cytokeratins 7 and 20 expression in differentiating colorectal adenocarcinomas from extraintestinal gastrointestinal adenocarcinomas: cytokeratin 7-/20+ phenotype is more specific than CDX2 antibody. Diagnostic Pathology $7:$ 9, 2012

18) Ramalingam P, Hart WR, Goldblum JR: Cytokeratin Subset Immunostaining in Rectal Adenocarcinoma and Normal Anal Glands. Arch Pathol Lab Med 125 : 10741077, 2001

19) Lisovsky M, Patel K, Cymes K, et al: Immunophenotypic Characterization of Anal Gland CarcinomaLoss of p63 and Cytokeratin 5/6. Arch Pathol Lab Med 131 : 1304-1311, 2007

20）森 志朋, 遠藤幸紀, 赤坂俊英 : 肚囲に Paget 現象を呈 した肛門管癌の 1 例. 臨皮 69:963-966, 2015

21) Selvaggi F, Guadagni I, Pellino G, et al: Perianal Paget's Disease Happening With Mucinous Adenocarcinoma of the Anal Canal: Managing Rarities. J Cutan Pathol 37 : 1182-1183, 2010

22）森谷行利, 冨岡憲明, 和泉明宏ほか：Pagetoid spread を ともなった肚門腺癌の 1 例. 日本大腸肛門病会誌 62 : 121-126, 2009

23）島田慎吾, 片岡昭彦, 高橋典彦ほか: Pagetoid spread を 呈した結腸人工肛門部癌の 1 例. 日消外会誌 $45 ： 672-$ 679,2012

24）小野里航, 中村隆俊, 小澤平太ほか：腹腔鏡下に手術し た pagetoid spread を伴う肚門管癌の 1 例. 日臨外会誌 $69: 2635-2639,2008$

25）升田貴仁, 早田浩明, 滝口伸浩ほか：Pagetoid spread を伴う肛門管癌を発症した Li-Fraumeni syndromeの 1 例. 日臨外会誌 $75: 1647-1652,2014$

26）村上拓生, 緒方 大, 中村晃一郎ほか：肚門管癌より生 じた続発性乳房外 Paget 病 原発性乳房外 Paget 病と の臨床的な相違点について. 皮膚臨床 58：1381-1384, 2016

27) Shutze WP; Gleysteen JJ: Perianal Paget's disease. Classification and review of management: report of two cases. Dis Colon Rectum $33: 502-507,1990$

28）林賢, 広田映五, 板橋正幸ほか：肚門管癌の臨床病 理学的検討. 日消外会誌 $22: 2414-2420,1989$
29）隅越幸男 : 肚門癌に関するアンケート調査報告. 日本大 腸肛門病会誌 $35: 92-97,1981$

30）竹内大輔, 小出直彦, 鈴木 彰ほか：肛門管癌の鼠径リ ンパ節転移郭清術の治療成績. 日臨外会誌 $75: 344-$ 352,2014

31）山本 淳, 石部敦士, 諏訪宏和ほか：下部直腸・肛門管 腺癌に対する鼠径リンパ節郭清の治療成績. 日消外会誌 $50: 95-103,2017$

32）鮫島伸一：肚門部上皮性悪性腫痬と悪性黑色腫の診 断・治療について 外科の立場から. 日本大腸肛門病会 誌 $61: 987-993,2008$

33）大腸癌研究会編：大腸癌治療ガイドライン医師用 2019 年版. 金原出版, 東京, 2019, p90

34）小林 信, 松浦謙二：腹会陰式直腸切断術後に二次性 Paget 病を指摘された直腸癌の 1 例. 日臨外会誌 68 ： 1234-1238, 2007

35）森本 守, 平井 孝, 金光幸秀ほか：Pagetoid spread を 伴った肛門管癌の 1 例. 日臨外会誌 71:2917-2921, 2010

36) Al Hallak MN, Zouain N: Extramammary Perianal Paget's Disease. Case Rep Gastroenterol $3: 332-337$, 2009

37）福岡宏倫, 長菩寿矢, 三城弥範ほか：Pagetoid spread を伴う肛門管腺癌に対して術前全身化学療法と化学放 射線療法を行い pCR が得られた 1 例. 日本大腸肛門病 会誌 $70: 81-87,2017$

38）清水康博, 長嶺弘太郎, 亀田久仁郎ほか：術前放射線療 法を行い根治切除した Paget 現象を呈する肚門管癌の 1 例。日臨外会誌 $75: 169-174,2014$

39) Yamada K, Saiki Y, Takano S, et al: Long-term Results of Intersphincteric Resection for Low Rectal Cancer in Japan. Surg Today $49: 275-285,2019$

40）藤吉健司，日高敦弘，主藤朝也ほか：Pagetoid spread を伴う肛門腺由来肛門管癌の 1 例。 日臨外会誌 76 ： 1118-1123, 2015

41）佐藤菜実，滝口伸浩，早田浩明ほか：肉眼的に明らかな 所見を認めなかった肚門管癌 pagetoid spreadの 1 例. 日臨外会誌 79：1288-1293，2018

42）伊藤大介, 中島紳太郎, 飯田直子ほか：肉眼的に皮膚病 変を認めなかった肚門腺由来の肚門管癌 Pagetoid spreadの 1 例. 日本大腸肛門病会誌 $65 ： 288-293,2012$ 


\title{
Treatment Outcome of Anal Canal Cancer with Pagetoid Spread in Japan
}

\author{
Yasumitsu Saiki, Kazutaka Yamada, Kazutugu Iwamoto, Masafumi Tanaka, \\ Mitsuko Fukunaga, Tadaaki Noguchi and Yasue Irei \\ Department of Gastroenterological Surgery, Coloproctology Center Takano Hospital
}

Anal canal cancer with pagetoid spread is rare. A review of the literature found that very little research has been done on cases with this kind of condition. One study reported on a case with pagetoid spread but the findings were inconclusive and required further research. The aim of this study was to determine the clinicopathologic characteristics and treatment outcome for anal canal cancer with pagetoid spread. A retrospective review of cases $(n=81)$ in Japan found that the average age of the patients was $\mathbf{7 0 . 2}$ years, $\mathbf{9 7 \%}$ had symptoms, $32 \%$ had difficulty with primary tumor identification, and cases with early-stage anal canal cancer, including intramucosal carcinoma, showed pagetoid spread. Immunohistochemistry was performed to differentiate between primary Paget's disease and pagetoid spread, and it was found that many cases were GCDFP-/CK20+/CK7+. Preoperative mapping biopsies to identify the areas for resection were performed on $46 \%$ of the patients, and rectal amputation was the result in many cases. The 5-year cumulative recurrence rate was $51.3 \%$ (inguinal lymph node and local recurrence) and the 5-year overall survival rate was $45.4 \%$. In conclusion, anal canal cancer with pagetoid spread had a poorer prognosis than anal canal cancer without pagetoid spread.

Key words: anal canal cancer, pagetoid spread, CK20, CK7, cumulative recurrence rate 